\title{
Esélyteremtés a könyvtárakban
}

2003-ban, a "fogyatékkal élők európai évében" a könyvtárak is bekapcsolódtak az esélyegyenlőség megteremtésébe. Egyik fő céljukká vált, hogy a fogyatékkal élők minden csoportját megfelelő információkkal lássák el. A közgyüjtemények - az érintett csoportok bevonásával és partnerkapcsolatok kialakítával - felhasználják mindennapi munkájukban a technikai újdonságokat. A könyvtárak számos új szolgáltatást vezettek be a hátrányos helyzetủek számára, speciális eszközökkel és dokumentumokkal segítve önálló ismeretszerzésüket. A tanulmány ezekről számol be, kitérve az ún. házon kívüli szolgáltatásokra és a könyvtári dolgozók speciális tanfolyamok keretében történő továbbképzésére is. Rámutat, hogy nem minden könyvtár rendelkezik megfelelően akadálymentes környezettel, speciális eszközparkkal és alternatív formátumú dokumentumokkal. 2005-ben zárult le az ellátottság feltárására indult kérdőíves felmérés, melynek eredményeit és tapasztalatait összegzi a szerző, megjelölve a további fejlesztés célszerü irányait is.

Kulcsszavak: intellektuális hozzáférés, közhasznú információszolgáltatás, fogyatékkal élók, könyvtár, Braille dokumentumok, esélyteremtés

\section{Szerzői információ:}

Várhelyi Eszter

Könyvtáros, a Berzsenyi Dániel Fốiskolán információmenedzser szakirányú könyvtárosi és történelem tanári diplomát szerzett. 2005-tól a Szegedi Tudományegyetem informatikus könyvtáros kiegészítô szakának hallgatója. Kutatási területe az esélyegyenlőség biztosítása a könyvtári ellátásban. Számos hazai szakmai konferencia résztvevóje és előadója. Legutóbbi tanulmánya 2005ben a Korszerü könyvtárak címú tanulmánykötetben jelent meg az esélyteremtés témájában.

E-mail: varhelyieszter@citromail.hu

Így hivatkozzon erre a cikkre:

Várhelyi Eszter. „Esélyteremtés a könyvtárakban”.

Információs Társadalom VI, 2. szám (2006): 123-128.

$=$ https://dx.doi.org/10.22503/inftars.VI.2006.2.12 $\rightleftharpoons$

A folyóiratban közölt müvek 
Várhelyi Eszter

\section{Esélyteremtés a könyvtárakban}

A 2003. év különleges jellege folytán - ez volt a „fogyatékkal élók európai éve” fontos kiindulóponttá vált a könyvtárak életében. Elindult egy olyan folyamat, aminek ma is tanúi és aktív résztvevôi vagyunk. A könyvtárak hivatalosan is be tudtak kapcsolódni az esélyegyenlőséget hirdetô mozgalmakba. Elkezdtük kialakítani a témán belül azt a területet, ahol a magunk eszközeit alkalmazni, saját elképzeléseinket megvalósítani tudjuk. Olyan szolgáltatásokat dolgozott ki a könyvtárostársadalom, amelyek a hátrányos helyzetúek életszínvonalát hivatottak javítani, s ennek keretében különös figyelmet kapott a fogyatékkal élók csoportja. A közgyújtemények egyre intenzívebben kísérték figyelemmel a megjelenő technikai újdonságokat, és használták fel azokat a mindennapokban. 2005-ben a Könyvtári Intézet oldaláról igény merült fel, hogy felmérje a hazai könyvtárak eszközellátottságát.

A kérdőíves felmérés egyik célja pontos helyzetkép felvétele volt a könyvtárak lehetốségeirôl és szolgáltatásairól, hogy ennek alapján dolgozhassuk ki az eljövendő évek fejlesztési irányait és a könyvtárak által a jövóben betölthetố lehetséges új szerepkört. A felmérés széles körben zajlott le, a résztvevók között szerepeltek városi és megyei könyvtárak, valamint néhány felsőoktatási intézmény is. A kérdések olyan infrastrukturális szükségleteket vizsgáltak, melyek egyrészt a fizikai, másrészt az intellektuális hozzáférési lehetôségekre vonatkoztak:

- Rendelkezik-e a könyvtár olyan eszközökkel, amelyek segítik a fogyatékkal élók könyvtárhasználatát?

- A fizikai hátránnyal élő́k hogyan tudják használni a könyvtárakat?

- Múködtet-e az intézmény házon kívüli szolgáltatásokat a hátránnyal élók számára?

A kérdőívek feldolgozása után általánosságban elmondható, hogy az intézmények eszközellátottsága nem mondható jónak. Ez fóként mennyiségi, és nem minőségi vonatkozásban értendô. Minôségi szempontból megállapítható, hogy a közkönyvtárak többsége nyitott a fogyatékkal élók csoportjának befogadására és segítésére, ez legjobban a dolgozók hozzáállásában nyilvánul meg. A könyvtárosok tenni akarásának és lelkesedésének köszönhetô, hogy beindultak olyan szolgáltatások, amelyek segítik az otthonukhoz kötött személyek információval való ellátását. Itt a házhozszállítás megszervezésére, letétek telepítésére és a nem rendszeresen üzemeltetett „bibliobuszokra" gondolok, A szándék tehát adott a könyvtárak oldaláról, s ehhez kellene társítani a szükséges anyagi forrásokat, amelyekkel lehetôségek és eszközök birtokába jutnának az intézmények.

Az így felvázolt kép természetesen nem minden esetben igaz: mint mindig, itt is vannak kivételek. Ha a felmérés eredményéról nem általánosságban beszélünk, 
akkor több szempont szerint lehet csoportosítani a könyvtárakat annak megfelelően, hogy mennyire tudják kiszolgálni a fogyatékkal élók részéról felmerülő igényeket. Az egyik szempont a könyvtár elhelyezkedése az országon belül, és ehhez kapcsolódóan a mérete. Az adatok értékelésekor egyértelmúen kimutatható volt, hogy a megyei könyvtárak ellátottsága jóval felülmúlja a kisebb helyi szervezetekét - ez a tény már ismert volt számunkra, de a felmérés most számadatokkal is alátámasztotta. A megyei intézmények között csak elvétve akad olyan, amelyik még nem alakította ki a megfelelő akadálymentes környezetet, illetve ahol nem tudnak speciális eszközöket és szolgáltatásokat nyújtani, vagy a megközelíthetőségük nem mondható jónak. (Rámpa 11 intézménynél van, küszöbnélküliség 12-nél, a megfelelő közlekedôtér pedig 14-nél megoldott, képernyố-felolvasó program 15 megyei könyvtárban áll rendelkezésre.) A városi és a felsőoktatási könyvtárak eszközparkja jóval „szegényebb”. Ennek egyik oka az, hogy a pályázati kiírások feltételeinek ezek a könyvtárak nehezebben felelnek meg, mint pl. a megyei közgyújtemények (megfelelő önrész, állománynagyság stb.).

A másik csoportosítási szempont a szolgáltatások köre, ami három nagy területre koncentrálódik:

- fizikai hozzáférés

- intellektuális hozzáférés,

- könyvtári dolgozók képzése.

Természetesen az elôző csoportosítással együtt érdemes vizsgálni a másodikat. A második felosztás elvi alapját a Pulman digitális útmutató adja, arra vonatkozóan, hogy a fogyatékkal élók hogyan férhetnek hozzá azokhoz a közkönyvtárakban található információkhoz, amelyek az általános használatra állnak rendelkezésre. Az útmutatóban gyakorlati javaslatokkal látja el a szakembereket, megtalálhatók benne a különféle típusú szolgáltatások és azok a kulcsfeladatok, amelyek segítenek ezek megvalósításában.

Visszatérve a felosztáshoz: a fizikai hozzáférés tekintetében a könyvtárak ugyanúgy az akadálymentesítô szabályoknak megfelelôen alakítják ki környezetüket, mint más intézmények. Intellektuális hozzáférés biztosításánál mutatkozik meg a könyvtár egyedi jellege. Speciális dokumentumok, alternatív formátumú anyagok és digitalizált információk - ezek mind hozzásegítik a felhasználót az egyéni igényeinek megfeleló tájékozódáshoz. Az alternatív formátumú anyagok csak centralizált előállítási és terjesztési rendszerek útján szerezhetók be, aminek eredményeként egyes intézményekbe kevesebb ilyen dokumentum jut el, és ez (a kisebb választék) az állomány összetételét is erôsen befolyásolja (minôségileg és mennyiségileg egyaránt).

Míg öregbetús és hangoskönyveket több könyvtár bocsát olvasói rendelkezésére, csak kevés intézmény tart állományában Braille-könyveket. Ezt a tényt a felmérés során feltárt adatok is alátámasztják, melyek a következố diagramokon láthatók. 

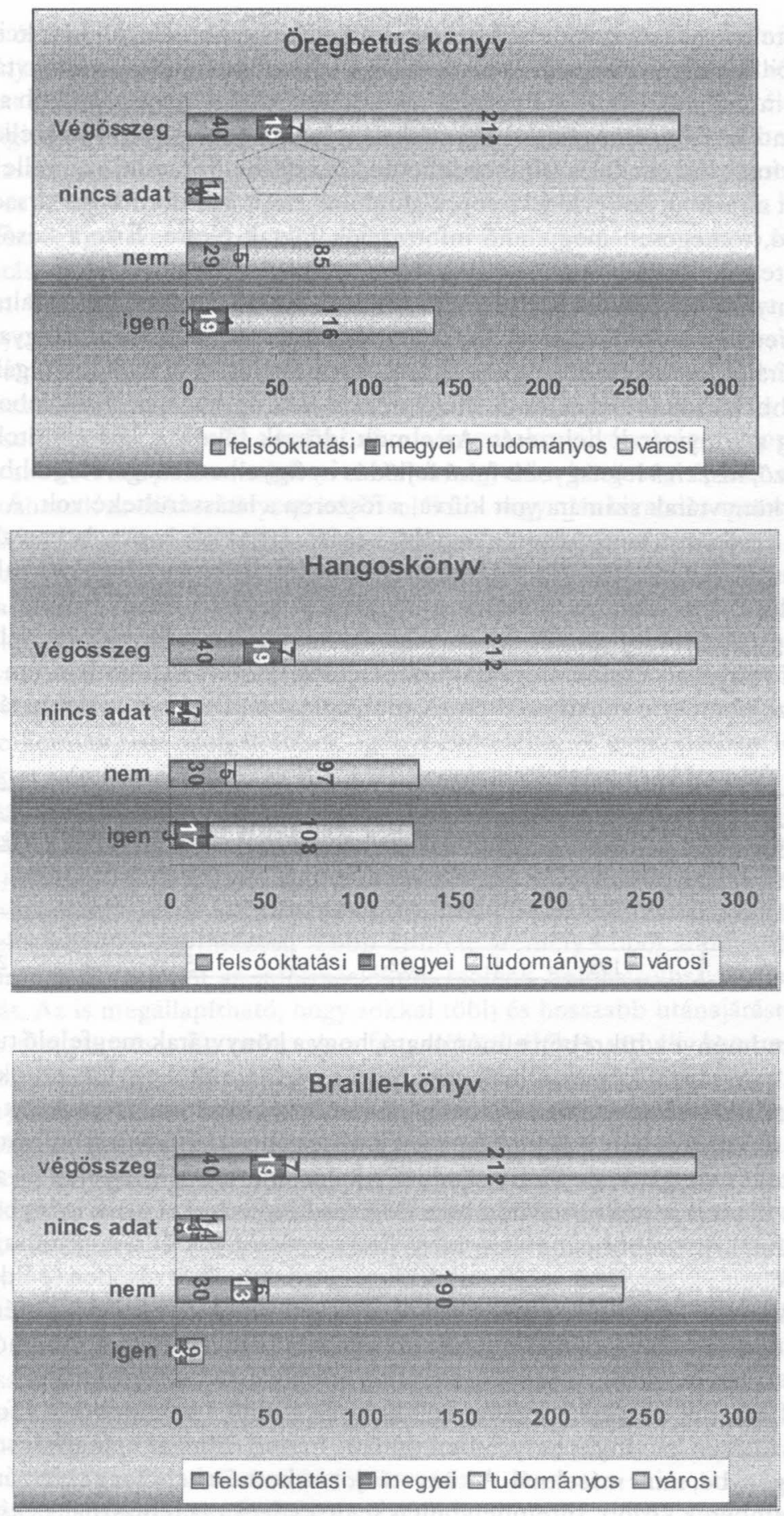
Az intellektuális hozzáférést biztosító különleges eszközök (pl. indukciós hurok, alternatív billentyúzet, vakbarát honlap, e-könyvek) szempontjából a könyvtárak helyzete jónak mondható, bár itt is a megyei szervezetek rendelkeznek erősebb apparátussal. Több intézményi támogatással nemcsak az aránytalan megyei és yárosi ellátottságot lehetne javítani, hanem korszerúbben lehetne hozzáférhetôvé tenni az intellektuális javakat is. Itt arra az új könyvtári szerepre gondolok, amit az információs társadalomban elszaporodó, tömegesen megjelenő információk hívtak életre. Erre a késóbbiekben még részletesen visszatérek.

A könyvtári dolgozók képzésének ügyét a Könyvtári Intézet vállalta magára, amely akkreditált továbbképzések keretében próbálja megteremteni a fogyatékosságtudat kultúráját, és felkészíteni a könyvtárosokat a fogyatékkal élôk kiszolgálására.

További szempont lehet, hogy a fogyatékkal élók egyes csoportjaira lebontva vizsgáljuk meg a könyvtárak helyzetét. Az elmúlt idôszak fóként a látássérültek számára volt kedvezô, hiszen a legnagyobb fokú fejlődés itt figyelhetố meg. A legtöbb pályázatban, ami a könyvtárak számára volt kiírva, a fôszerep a látássérülteké volt. A felmérésben is erre a csoportra vonatkozott a legtöbb kérdés, így velük kapcsolatban alakult ki a legrészletesebb helyzetkép. A siketek és nagyothallók helyzete a fogyatékkal élók csoportján belül is speciális, így ellátásuk a könyvtárak számára nehéz feladat. Az elmúlt években egyre többször merült fel az az igény, hogy a könyvtárosok rendelkezzenek jeltolmácsi vizsgával. Ennek megvalósítása jelenleg kezdeti stádiumban van. A felmérésben is szerepelt erre vonatkozó kérdés, melynek az eredménye az alábbi táblázatban látható:

\begin{tabular}{|l|c|c|c|c|}
\hline & \multicolumn{3}{|c|}{ Jeltolmács } & \\
\hline Könyvtártípus & nincs & nincs adat & van & végösszeg \\
\hline Felsőoktatási & 32 & 6 & 2 & 40 \\
\hline Megyei & 11 & 3 & 5 & 19 \\
\hline Tudományos & 6 & 1 & & 7 \\
\hline Városi & 195 & 12 & 5 & 212 \\
\hline
\end{tabular}

Az eredmények tükrében elmondható, hogy a könyvtárak megfelelő tudásbázissal és fogékonysággal készen állnak arra, hogy a partnerekkel együtt, munkamegosztásban elvállalják a fogyatékkal élók eligazítását és segítését az információk sokaságával átsző́tt társadalomban. A felmérés, mint említettem, elsôsorban az infrastrukturális szükségleteket vizsgálta, de nem terjedt ki a valós információigényekre és a könyvtár lehetséges új szerepére a társadalomban. (Miért a könyvtárat vegyük igénybe információforrásként?) Az utóbbi pár évben megváltozott viszonyok és a magyar sajátosságok miatt a jövóben a könyvtárak segíthetnek olyan feladatok elvégzésében (példaként említve a hétköznapi életvitelhez nélkülözhetetlen ismeretek egy helyról történő beszerzését), amelyeket a jól múködő nyugati társadalmakban valamilyen más módon oldanak meg. Az információk többsége elérhetố, azonban szétszórt formában van jelen. Tudni kell mit, hol és milyen módon kell keresni. Ebból a szempontból a fogyatékkal élốk többszörösen hátrányos helyzetben vannak, hiszen náluk az utánajárás sokkal több idốt vesz igénybe, mint másoknál. A könyvtár jelenthetné a kapcsot a szétszórt információk és az emberek között. Interoperabilitás segítségével az a felhasználó, akit egy bizo- 
nyos téma érdekel, könnyebben találhat hasznos tájékoztatást, ha az információkat egy helyról tudja beszerezni. Az embereknek naprakész információra van szükségük a civil társadalmat alkotó szervezetek köréról. Az ilyen jellegű adatok teljes mértékben alkalmasak a digitalizálásra, s ezáltal sokkal szélesebb kör számára elérhetốvé tehetôk. Erre a legalkalmasabb a könyvtár honlapja, amelyen keresztül elérhetố lehet minden helyi szervezet és válogatott országos intézmények is. A honlapon feltüntethetô a helyi szociális és egészségügyi szervezetek elérhetôsége, továbbá a polgári tanácsadó szervek és a közigazgatási intézmények jegyzéke.

Ezen keresztül lehetôséget kell adni az élethosszig tartó tanulásra, illetve az e-kormányzati lehetőségek aktív igénybevételére. Ez utóbbinak a megvalósítása - a közkönyvtárak eddig kialakult jellege miatt - teljes mértékben megoldható. Az állampolgári részvételnek mindig is fontos színterei voltak ezek az intézmények, több okból is, de elsôsorban azért, mert itt a helyi önkormányzatok nyilvánosságot kaptak. Elôfordult, hogy az adott településen a könyvtár volt az egyetlen közösségi épület, ahol a lakosok találkozhattak az önkormányzati képviselókkel vagy más hivatalos szervezetek dolgozóival. Mára ez a funkció átalakult, de alapgondolata ugyanaz maradt. A személyes találkozók mellett (vagy azok helyett) más kommunikációs csatornák is rendelkezésre állnak ahhoz, hogy az állampolgárok felvegyék a kapcsolatot kormányhivatalnokokkal, képviselookkel, helyi szervezetekkel. Az online hozzáférhetôség révén a szolgáltatások otthonról vagy a munkahelyekról is elérhetôk. Megteremtôdött az e-ügyintézés, amely most éli virágkorát. A könyvtárak az online ügyintézés segítése révén tudnak bekapcsolódni az e-kormányzati szolgáltatások igénybevételébe. A gyakorlatban legtöbbször elektronikus számlabefizetésekre, nyomtatványok kitöltésére és időpontok egyeztetésére van szükség: a könyvtárak segíthetik az elektronikus ügyintézéssel való barátkozást. Mindez kihatással van a fogyatékkal élók hétköznapjaira is. A szétszórt ismeretek nehezen jutnak el a megfelelő helyre a megfeleló időpontban, mivel kevés olyan könyvtár van, amely - az önkormányzatokhoz hasonlóan - beépítette volna szolgáltatásaiba az elektronikus ügyintézést. Több érintett személy ebból adódóan nem, vagy csak késốn értesül azokról az információkról, melyek befolyásolhatják életminősége színvonalát. Az is megállapítható, hogy sokkal több és hosszabb utánajárást igényel az ismeretek megszerzése. Ez nemcsak a fogyatékkal élóket terheli, hanem közvetlen hozzátartozóikat is.

Tény, hogy a hátrányos helyzetú személy nem mindig tudja, hogy kihez, mikor és hogyan lehet információért fordulni. Ez kihatással lehet munkavállalására, tanulására, rehabilitációjára, egészségi állapotára stb. A mostani helyzeten úgy javíthatunk, hogy biztosítjuk a közösségi információkhoz való széles körú hozzáférést. Ezenkívül partnerkapcsolatot létesítünk közintézményekkel, önkéntes és magánszervezetekkel, melyek segítségével létrehozhatjuk a közösségi portálokat. Közvetítóként és koordinátorként pedig biztosítjuk a színvonal fenntartását, illetve a tartalom állandó frissítését.

Arra a kérdésre, hogy miért alkalmas a könyvtár a fogyatékkal élók csoportjának befogadására és ellátására, összefoglalva a könyvtárak alábbi jellemző vonásainak felsorolásával adhatunk választ.

A könyvtár

- megfelelő szellemi tókével bír;

- információs források tárháza; 
- figyelemmel kíséri a valós felhasználói igényeket, s ehhez mérten alakítja ki szolgáltatásait;

- a mindennapi élethez szükséges adatokkal rendelkezik;

- számos szervezettel múködik együtt;

- személyre és csoportra szabott szolgáltatásokat nyújt;

- közösségi találkozópont.

A fentiekben leírtak csak akkor válnak valóra, ha megszívleljük a következố mondást: „Tervezz a sérülteknek, és az mindenkinek jó lesz. Tervezz az épeknek, az csak az épeknek lesz jó, de már az idôs embereknek például nem." ${ }^{1}$

\section{Felhasznált források}

Pulman digitális útmutató www.ki.oszk.hu/pulman

Calimera digitális útmutató www.ki.oszk.hu

Dr. Bartos Éva: Esélyek és hátrányok a könyotári ellátásban

www.sk-szeged.hu 